\title{
Challenges and Prospects of Cooperatives in Ethiopia with Reference Sough Gondar Zone- Ethiopia
}

\author{
Abebaw Yenesew Dejen Debeb \\ Lecturers in the Department of Accounting and Finance, Debretabor University- Ethiopia
}

\begin{abstract}
Cooperatives in Ethiopia are playing an active role in the fields of banking, input and output marketing, agroprocessing, storage, dairy, and many other social and economic activities. Cooperatives have inherent advantages in tackling the problems of poverty alleviation, food security and job creation. They are also considered to have immense potential to deliver goods and services in areas where both the state and the private sector have failed. Serious efforts are being made to strengthen capital of cooperatives base through increasing members' subscription, mobilization of savings and value addition. The establishment of agricultural cooperative in Ethiopia is significantly associated with and responsible to overcome the problems that individual farmer could not solve solely. The cooperatives were thus permitted to exchange their members' product, improve market access and directly provide their produce to the market through improving the bargaining power of farmer members. Ethiopian Government has also made efforts for cooperatives development that can be taken as opportunities. However, studies show that the growth of cooperatives in different parts of the country is not up to the expectation. Therefore, this study was conducted with the objective of assessing the challenges and prospects for agricultural cooperatives in south Gondar Zone, Ethiopia. In order to conduct the study, primary data were collected from the members of sampled cooperatives and supported by secondary data. The data were analyzed using both qualitative and quantitative techniques. The findings of the study revealed that there are ample prospects for the growth of the agricultural cooperatives like the legal framework; support of the cooperatives union; positive members' attitude towards cooperatives; women involvement in leadership. However, agricultural cooperatives in the study area faced many challenges including lack of sense of ownership and lack of follow up and control system by members; lack of commitment, members little awareness about cooperatives, low participation of members in their cooperatives, mistrust; failure of management committee to serve the members' interest; management committees' little knowledge about cooperative proclamations, rules and bylaws, limited training access; limited professional support and follow up to cooperatives; failure to adapt the experience of other model cooperatives; little effort to promote cooperative policies, strategies, proclamations, rules and regulations, lack of commitment to find out the problems of cooperatives and fill the gap; fail to organize and provide adequate, quality and timely information on cooperatives. The above challenges may be easy if educated cooperative professionals were invited to lead the sector. Training to office bearers and education to the members pertaining to their specific needs is another important aspect for cooperatives.
\end{abstract}

Keywords: Cooperatives in Ethiopia, Agricultural cooperatives, challenges and prospects of cooperatives in Ethiopia. Cooperatives in Sough Gondar in Ethiopia.

DOI: $10.7176 / \mathrm{EJBM} / 11-34-03$

Publication date: December $31^{\text {st }} 2019$

\section{Introduction}

Agriculture is the foundation for Ethiopian economy, and the overall economic growth of the country is highly linked to the success of the agriculture sector. In 2012/13, real GDP growth was 9.7\% moderately lower than the $11.4 \%$ growth a year earlier. Accordingly, agriculture accounts for about $43 \%$ of the country's gross domestic product (GDP), $90 \%$ of export, and $85 \%$ of employment (NBE, 2013).As agriculture continues to be an important to the Ethiopian economy, the cooperative sector providing vital support services and play a crucial role for the transformation of the agriculture sector. It play an active role in the fields of banking, input and output marketing, agro-processing, storage, dairy, and many other social and economic activities.

Cooperation is not an invention of the peoples of the West or the North, nor is it a recent phenomenon (Krishna and Kulandeiswamy, 2000). In early human societies people learned to cooperate and work together to increase their success in hunting, fishing, gathering foods, building shelter, and meeting other individual and group needs. Historians have found evidence of cooperation among peoples in early Greece, Egypt, Rome and Babylon, among American and African population groups, and in virtually every human society.

\section{Literature Review:}

Concepts of cooperatives

The International Cooperatives Alliance (ICA, 1995) defines cooperative, as "an autonomous association of persons, united voluntarily to meet their common economic and social needs through jointly-owned and democratically-controlled organization/enterprise". In its own definition, the International Labor Organization 
(ILO) also points out that members accept a fair share of the risks and benefits of their cooperative undertakings (ICA, 1995).

A cooperative is a business voluntarily owned and controlled by its member patrons, and operated for them and by them on a nonprofit or cost basis. A cooperative enterprise belongs to the people who use its services, i.e., members control it, and its gains are distributed to the members in proportion to the use they make of its services.

The primary goal of a cooperative is to meet members' needs in an economical, efficient manner, whereas the goal in the investor-oriented corporation, the partnership, and the sole proprietorship is to maximize profits for the owners of the business (Marvin A., 1980).

Cooperative may render at least four valuable services at capitalistic system of which they are a part: 1) enhance private property, 2) preserve market competition, 3) retain profit motive and 4) maintain and strengthen the individual consumer and entrepreneur. The main purpose of the cooperatives is to make a profit for its patrons or users of the cooperative, not for its investors. The member of cooperative serves themselves. They are both the owners and users of the service. A contractual arrangement between the cooperative and the member patrons requires that all margin above the cost of production be returned to the member patrons in proportion to their business with the cooperative (Zusman, 2005).

Over the years, various definitions have been given of cooperation. Among the definitions available in the cooperative literature Dooren (1986) defined cooperative as an association of members, either personal or corporate, which have voluntarily come together in pursuit of common economic objectives.

The International Cooperative Alliance (ICA), an apex organization that represents cooperatives worldwide, has also defined cooperative as: An autonomous association of persons united voluntarily to meet their common economic, social and cultural needs and aspirations through a jointly owned and democratically controlled enterprise.

In general, according to Chambo (2009), the definition of cooperatives is built on four major catch words; first, they are formed by groups of people, who have a specified need or problem.

Second, the organization is formed freely by members after contributing to its assets. Thirdly, the organization formed, is governed democratically in order to achieve desired objectives on equitable norms, and fourth, it is an independent enterprise promoted, owned and controlled by people to meet their needs.

\section{The Concepts of Agricultural Cooperatives}

Agricultural cooperatives are farmers' organizations that are established based on their interest to solve their common problems and are managed by elected committee members. Even though, cooperatives are autonomous and independent organization, they have to be guided by internationally accepted principles and since they are established under those principles, agricultural cooperatives are expected to be effective in serving their members in terms of input supply, output marketing, fair distribution of benefits, credit supply, providing current market information and facilitating innovation diffusion (Federal Cooperative Agency, 2007).

Moreover, agricultural cooperatives are member-based organizations, i.e. they are owned and controlled by their members. Ideally, member ownership is defined both in economic terms (members are shareholders) and in psychological terms (members feel ownership of the organization). Member control is defined by members holding the decision rights on both the activities and investments of the agricultural cooperatives, both ownership and controls are collective in nature.

According to Federal Cooperative Agency (2007), agricultural cooperatives are recognized as an important instrument for socioeconomic improvement of the community. This importance is recognized in their definition, which considers cooperatives to be: An association of persons who have voluntarily joined together to a common end through the formation of a democratically controlled organization, making equitable contribution to the capital required and accepting a fair share of the risks and benefits of the undertaking, in which the members actively participate.

\section{Empirical studies}

Joe Folsom (2003) conducted a study on the economic impact of cooperatives in Minnesota and indicated that cooperatives as a form of business have been a part of Minnesota's economic and cultural history. Its 1,026 cooperatives make it one of the leading states in the country with this form of business structure. The study employed input-output method of analysis which provides some measures of quantifying economic and employment impacts of businesses. With this tool, he measured the direct effects attributable to the firm, those resulting from purchases made by the firm, and the induced effects as a result of local spending by firms attributable to the demand change resulting from the firm's actions

Some transient problems have confronted the agricultural cooperatives in Ethiopia. Such as: financial constraints, transportation problems, shortage of skilled manpower, delay in provision of supplies like fertilizer, improved seed etc. (Mekonnen, 1992).

Currently the government of Ethiopia is encouraging and supporting the establishment of cooperatives in 
various spheres of the counter's economy. As a result, the cooperative movements is expanding, diversifying and growing at a rapid speed. But like other developing countries, the cooperative sector of Ethiopia also faces organizational and structural, resources, political and legal, and monitoring and evaluation problems (FCA, 1998).

\section{Organizational and Structural challenges}

Many cooperatives in Ethiopia are agricultural cooperatives with limited means. Unfortunately, government has very limited personnel and other resources to conduct awareness creation activities (FCA, 1998).

\section{Resources and Capacity Challenges}

Generally the cooperatives face financial problems in order to expand their business activities and hire professionals to become more effective in their operations (FCA, 1998).

\section{Political and Legal challenges}

The concept of the people to accept cooperatives as an economic alternative was affected due to the political interference in the affairs of cooperatives and delay in settlement of disputes.

The cooperative proclamation gives clear direction and guidelines to run a cooperative as an autonomous association. But it is not reached to the people fully yet (ibid).

\section{Monitoring and Evaluation challenges}

In Ethiopia with predominantly peasant, underdeveloped infrastructure, very limited government capacity, cooperative could have a very valuable option to resort. However, Yigremew (1998) revealed that Ethiopia experience with valuable rural organization such as agricultural cooperatives has become a missed opportunity. Most studies in Ethiopia have shown that cooperatives were a threat, source of insecurity and burden. This was witnessed by the response of most cooperative members following the announcement of the mixed economy and the ultimate overthrow of the Derg regime. In connection to this, Dessalegn (1992) revealed that when the military regime came to an end, several thousands of rural and urban based cooperatives of various types with multi-million memberships were established across the country. Not surprisingly, such societies were short lived since they were established in contravention of the universally accepted values and principles of cooperatives. Also Dessalegn (1992) pointed out that only a few weeks after the Ethiopian government announced the mixed economic policy, a greater majority of cooperatives were dissolved by their own members.

Just after the 1974 revolution, the military regime enacted proclamation No. 71/1975 to prove the nationalization of rural lands. The rural land reform policy in line with the socialist line of development triggered the establishment of cooperatives (Yigremew and Haile, 1999).

In the study of cooperative movement in Ethiopia at early days, Kebebew (1978) emphasized that the state was committed to expand collective agriculture. This commitment manifested by the material and technical investment accompanied by educational programs designed to raise the social and political consciousness of the peasants. State investment in agriculture designed to modernize the methods of agricultural production is likely to attract those peasants who are questioning about the success of collective production.

Daniel (2006) studied the performances of primary agricultural cooperatives and members decision to use as marketing agents. On his findings he discovered that farmers' usage of the cooperative as a marketing agent for farm produces increase if the cooperatives provide them with different additional services such as dividend payment and supplying of inputs (fertilizer, chemicals, feed and seed).

Studies done so far as mentioned earlier concentrated more on agricultural cooperatives formation and performance. This study therefore, tried to narrow the research gap paying particular attention to challenges and prospects of agricultural cooperatives in south Gondar Zone, Ethiopia.

\section{Statement of the Problem:}

Ethiopian economic growth strategy formally set forth in 1995; as the Agricultural Development Led Industrialization (ADLI) gives significant emphasis on Agriculture and Development as an engine of pro-poor growth (FDRE, 2007). This strategy is one mechanism of poverty reduction which includes the Sustainable Development and Poverty Reduction Program (SDPRP) approved in 2004, Food Security Strategy (FSS) and most recently the 2006 Plan for Accelerated and Sustained Development to End Poverty (PASDEP, 2008). To implement this strategy, cooperatives are one of the vital actors that the government has assigned agricultural cooperatives with the responsibility of improving small holder productivity and commercialization.

Similarly, both Tesfaye (1995) and Zerihun (2003) noted that the importance of cooperatives in carrying out coordinated and comprehensive development efforts; that they are indispensable in Ethiopia where farm holdings are small, low application of modern technology and subsistence nature of production with low marketable surpluses. Nevertheless, in Ethiopia studies have shown that cooperatives were taken as a threat, a source of insecurity and burden. The enactment of the proclamation No. 147/1998 facilitated the establishment of a number 
of cooperatives among which agricultural cooperative unions are at the front line. Some of the salient problems that initiated the establishments were weak organizational structure and lack of capacity to address the needs of their members.

According to Huss et al (1993), in many cases cooperatives were vehicles for political patronage and nepotism, and were subjected to capture by local elites. Even with the cooperative movements; there was support for a directive and coercive roles on government vis-a-vis cooperatives in developing countries (ICA, 1966). Thus, coupled with the fact that production was taken place in remote areas characterized by poor infrastructure, low standard of living and education levels has exacerbated the problem (Milford, 2004).

However, the movement towards the production and marketing of agricultural products to the market has a recent phenomenon and even the agricultural cooperatives are relatively recent establishments. Thus, it seems that no substantial attempts have been made to assess the prospects presented and to examine and the constraints encountered by agricultural cooperative.

Therefore, it is worth mentioning that a closer examination of the challenges and prospects of agricultural cooperatives is a paramount importance in taking preventive actions and corrective measures, and exploit the existing prospects in South Gondar Zone.

\section{Objectives of the study}

\section{General Objective of the study}

The main objective of the study was to examine the challenges and prospects of agricultural cooperatives in South Gondar Zone.

\section{Specific Objectives of the study}

- To identify the internal challenges that hamper Agricultural Cooperatives performance in South Gondar Zone.

- To identify the external challenges that hamper Agricultural Cooperatives performance in South Gondar Zone

- To investigate the prospects for agricultural cooperatives performance in the study area

- To provide policy makers with a proposal for more support strategies which will enhance performance of cooperatives and increase benefits to members

\section{Research questions}

- What external challenges that hamper Agricultural Cooperatives performance in South Gondar Zone?

- What internal challenges that hamper Agricultural Cooperatives performance in South Gondar Zone?

- What are the prospects for agricultural cooperatives in South Gondar Zone?

\section{Significance of the study}

Problems in rural areas are not easily tackled only by individuals or single farmer's resources, but needs an integration of individuals who have common interest and problems by establishing their own organizations to pool their resources, knowledge and wise utilization of opportunities. This can bring sustainable benefit for individual members in particular and for cooperatives in general.

Based on this, the study generated information on diverse set of issues related to challenges and prospects of agricultural cooperatives in the study area. To this end, it can provide information to farmers, administrators, cooperative promoters, and other development agents. Moreover, the finding of the research will be used as a benchmark for doing further research in the same line by other researchers in the future.

\section{Scope and limitations of the study}

The study is limited to agricultural cooperatives located in South Gondar Zone. Ethiopia. Hence, it is limited to address the challenges and prospects of agricultural cooperatives in South Gondar Zone.

\section{Research Methodology}

\section{An Overview of Amhara National Regional State}

Amhara National Regional State is one of the nine Regional States in the Federal Democratic

Republic of Ethiopia, it is found in the north-western part of the country. The Region is bounded by Tigray Region in the north, Oromia Region in the south, Afar Region in the east, BenishangulGumuz Region in the southwest, and the Sudan in the northwest. It is divided into 8 Amhara nation administrative zones, which are East Gojjam, West Gojjam, ,North Gondar, South Gondar, North Wollo, South Wollo, North Shewa, and three other nations zone which are called Oromia zone(oromo nation), Awi zone(Awi nation) and Wag Himera zone(Himira nation). The total area of the Region is 170,752 square kilometres, which covers $15 \%$ of the total area of the country. Out of the total area, $27.3 \%$ is under cultivation, $30 \%$ is under grazing, $14.7 \%$ is covered by forest, bush and herbs, and $18.9 \%$ is currently not used for productive purposes. The remaining $9.1 \%$ represents settlement 
sites, swampy areas, and lakes. Based on the traditional agro-ecological zones, the Region has four climatic zones, namely, wurch or very cold (4 \%), Dega or cold (25\%), Woina-Dega or moderate (44\%) and Kolla or warm (27\%). The Region has an average annual rainfall of 200 to 1600 millimeters and has a mean annual temperature of 10 to $25^{\circ} \mathrm{c}(\mathrm{BoFED}, 2010)$.

According to 2007 Ethiopia National Housing and Population Census, the population of the Region is estimated to 17,221 , and 977 , of whom 8,641,580 are male and the rest 8,580,396 are female. $87.7 \%$ of the population is living in rural areas which are mainly engaged in mixed farming.

\section{An Overview of South Gondar Zone}

South Gondar is a Zone in the Ethiopian Amhara Region. This zone is named for the city of Gondar, which was the capital of Ethiopia until the mid-19th century, and has often been used as a name for the local province.

South Gondar is bordered on the south by MisraqGojjam, on the southwest by MirabGojjam and Bahir Dar, on the west by Lake Tana, on the north by Semien Gondar, on the northeast by Wag Hemra, on the east by SemienWollo, and on the southeast by DebubWollo; the Abbay River separates Debub Gondar from the two Gojjam Zones.

The highest point in South Gondar is Mount Guna (4,231 meters). Towns and cities in this zone include Addis Zemen, Debre Tabor and Wereta.

Based on the 2007 Census conducted by the Central Statistical Agency of Ethiopia (CSA), this Zone has a total population of 2,051,738 and increase of $16 \%$ over the 1994 census, of which 1,041,061 are men and 1,010,677 women. With an area of 14,095.19 square kilometers, South Gondar has a population density of 145.56; 195,619 or $9.53 \%$ are urban inhabitants. A total of 468,238 households were counted in this Zone, which results in an average of 4.38 persons to a household, and 453,658 housing units. The main ethnic group reported in South Gondar was the Amhara (99.7\%); all other ethnic groups made up $0.3 \%$ of the population. Amharic was spoken as a first language by $99.7 \%$; the remaining $0.3 \%$ spoke all other primary languages reported. $96.14 \%$ practiced Ethiopian Orthodox Christianity, and $3.68 \%$ of the population said they were Muslim.

The 1994 national census reported a total population for this Zone of 1,768,732 in 393,311 households, of whom 904,796 were men and 863,936 women; 116,702 or $6.6 \%$ of its population were urban dwellers at the time. The largest ethnic group reported in Debub Gondar was the Amhara (99.89\%); all other ethnic groups made up $0.11 \%$ of the population. Amharic is spoken as a first language by $99.92 \%$; the remaining $0.08 \%$ spoke all other primary languages reported. $95.49 \%$ practiced Ethiopian Orthodox Christianity, and $4.36 \%$ of the population said they were Muslim.

According to a May 24, 2004 World Bank memorandum, 4\% of the inhabitants of South Gondar have access to electricity, this zone has a road density of 66.1 kilometers per 1000 square kilometers (compared to the national average of 30 kilometers), the average rural household has 1 hectare of land (compared to the national average of 1.01 hectare of land and an average of 0.75 for the Amhara Region) and the equivalent of 0.6 heads of livestock. $14 \%$ of the population is in non-farm related jobs, compared to the national average of $25 \%$ and a Regional average of $21 \% .49 \%$ of all eligible children are enrolled in primary school, and $9 \%$ in secondary schools. $55 \%$ of the zone is exposed to malaria, and none to tsetse fly. The memorandum gave this zone a drought risk rating of 514 .

\section{Research Design}

The major focus of the study is description of information related to challenges and prospects of agricultural cooperatives by collecting cross sectional data from the study area. So, the research method used for the study was explanatory research design to answer research questions.

\section{Sampling Technique}

The research was conducted in South Gondar Zone. South Gondar Zone is selected purposively because of the availability of required data in agricultural cooperatives for the study.

\section{Sample Frame}

The study focused on agricultural cooperatives. In the study area there were a total of 794 primary agricultural cooperatives having 632,317 members.

\section{Sample selection of the study}

In order to conduct the study in a representative way and to increase its reliability and validity a two staged random sampling technique was employed in selecting the samples.

In the first stage, from the total sample frame (794) cooperatives only 456 cooperatives of the sample frame having life span of three years and above because taking longer life span cooperatives provides necessary data.

In the second stage, the sample size of the study or the number of member respondents was determined by using Kothari (2004) sampling design formula: 
Where:

$$
\frac{n=z^{2} p q N}{e^{2}(N-1)+z^{2} \mathbf{p ~ q}}
$$

$\mathrm{n}=$ sample size $=816$

$\mathrm{N}=$ total population $(632,317)$

$\mathrm{Z}=95 \%$ confidence interval under normal curve (1.96)

$\mathrm{e}=$ acceptable error term $(0.05)$ and

For this study, 816 sample respondents were taken. Finally, the sample respondents were selected by using simple random sampling.

\section{Data Types, Source and Methods of collection}

Data were collected from both primary and secondary sources. Primary and secondary data will be collected to answer the research questions and to achieve objectives of the study. Semi -structured interview schedule was used to collect primary data. For the sake of triangulating, data were collected from management committee members of sample cooperatives by conducting focus group discussions (FGD); eleven (11) FGDs were conducted in each woreda with 66 management committee members of sample cooperatives. Moreover, key informants interview (KII) were employed with 22 woreda level cooperative promoters and 2 zonal cooperative promoters through interview guide check list. Pre- testing of semi- structured interview schedule was done before formal data collection. To make the communication easier during collection of data from the respondents, semi-structured interview schedule was translated into Amharic. 24 enumerators were recruited and trained about the techniques of data collection. Continuous supervision was made by the researchers during data collection for maintaining the validity and reliability of the data. Secondary data, mainly concerning challenges and prospects were collected from sample cooperatives and from woreda and zonal cooperative promotion offices.

\section{Method of Data Analysis}

Both qualitative and quantitative techniques of data analysis were used to describe and analyze the research questions. The data collected from household survey were organized, coded and entered in to statistical package for Social Sciences (SPSS) Version 16. And, descriptive statistics such as frequency, percentages, graphs and tabular ways of data presentation were used and then the figures were analyzed and interpreted.

On the other hand, data gathered from interview, and focus group discussions were first categorized thematically, and written up in to narrative, then it was followed by analysis and interpretation.

\section{Results and Discussion:}

Demographic and socio-Economic characteristics of respondents

\section{Distribution of the respondents by age group}

It is the number of completed years of the general assembly member from the time of birth till the time of the survey conducted. The result indicated that $16.5 \%$ of the respondents were within the age group of 14-30 years, $21.8 \%$ within the age group of 31-40 years, $33.1 \%$ within the age group of $41-50$ years and the rest $28.6 \%$ were above 50 years old. It implies the majority of the members were above 40 years old. As table 7 below shows, the average age of the respondents was 43.56 with a standard deviation of 11.569 . The minimum and maximum age of them was 20 and 65 respectively.

Table 7. Distribution of the respondents by age group

\begin{tabular}{|c|c|c|}
\hline Variable & Statistics & Members (N)= 816 \\
\hline \multirow{2}{*}{ Age } & Mean & 43.56 \\
\cline { 2 - 3 } & Standard deviation & 11.569 \\
\cline { 2 - 3 } & Maximum & 65 \\
\cline { 2 - 3 } & Minimum & 20 \\
\hline
\end{tabular}

Source: own survey, 2018

\section{Respondents' sex and marital status}

As far as their marital status is concerned, the respondents were categorized as single, married, divorced, and widowed. However, the result of the conducted survey shows the respondents have fallen under three categories only, as single/never married, married, and divorced. 93.2 percent were married, 3.8 percent were unmarried, and the rest 3 percent were divorced. This implies that the vast majority of respondents were married. 
Table 8: Respondents' sex and marital status

\begin{tabular}{|l|l|r|r|}
\hline Characteristics & Category & \multicolumn{2}{|c|}{ Respondents (N) = 816 } \\
\cline { 2 - 4 } & & Frequency & Percent \\
\hline \multirow{2}{*}{ Sex of the respondents } & Male & 753 & 75.2 \\
\cline { 2 - 4 } & Female & 63 & 24.8 \\
\cline { 2 - 4 } & Total & 195 & 100 \\
\hline \multirow{2}{*}{ Marital status of the respondents } & Single & 57 & 3.8 \\
\cline { 2 - 4 } & Married & 759 & 93.2 \\
\cline { 2 - 4 } & Divorced & 149 & 3 \\
\cline { 2 - 4 } & Total & 816 & 100 \\
\hline
\end{tabular}

Source: own survey, (2018)

\section{Distribution of the respondents by family size}

It is the number of family members of the respondents. It was expected that members of general assembly of the union having larger family size would have higher expenditure for consumption and other expenses and spend most of their time to full fill those expenses. Table 10 shows that the average family members of the sample respondents were 6 persons. The largest family members were 12 and the smallest was 2 . This implies that the mean value of family size found out in this survey is greater than the national average family size of 5 persons and the total Amhara region average family size of 5 persons.

Table 10: Family size of the respondents

\begin{tabular}{|l|l|c|}
\hline Variable & Statistics & Members $(\mathbf{N})=\mathbf{8 1 6}$ \\
\hline \multirow{3}{*}{ Family size } & Mean & 6 \\
\cline { 2 - 3 } & Standard deviation & 2.476 \\
\cline { 2 - 3 } & Maximum & 12 \\
\cline { 2 - 3 } & Minimum & 2 \\
\hline
\end{tabular}

Source: own survey, 2018

Distribution of respondents by educational level

This refers to the grades completed through formal schooling. It was considered that a member having longer years of formal schooling could have a better awareness and knowledge about cooperatives and in turn he/she would increase his participation in cooperatives. As to table 11 below, it was found that from the total respondents about $23.3 \%$ were illiterate, $10.5 \%$ were able to read and write, $21.1 \%$ belonged to grade $1-4,37.6 \%$ were between grade 5 and 8 and the rest $7.5 \%$ were between grades 9-12. This implies the vast majority of the respondents had no problem of reading and writing.

Table 11: Distribution of the respondents by educational level

\begin{tabular}{|c|c|c|c|c|c|c|}
\hline \multirow[b]{2}{*}{ Characteristics } & \multicolumn{6}{|c|}{ Category } \\
\hline & Illiterate & Read and write & $1-4$ & $5-8$ & $9-12$ & Total \\
\hline Frequency & 190 & 86 & 172 & 307 & 61 & 816 \\
\hline Percent & 23.29 & 10.5 & 21.11 & 37.6 & 7.5 & 100 \\
\hline
\end{tabular}

Source: own survey, 2018

\section{Challenges of Cooperatives:}

There are various challenges which slow down cooperative growth. For simplicity of analysis, challenges of the sampled agricultural cooperatives are discussed below by classifying them into two broad categories.

\section{Internal Challenges}

As far as internal challenges of cooperatives are concerned, it is related with management committee, general assembly and cooperatives' employees, physical and financial properties, the system and procedures also constitute the initial or organizational part of the cooperatives. Therefore, limitation in the capacity management committee, initial capital, members participation in management of cooperatives, transparency and accountability of the management committee and management, awareness on duties and responsibilities, member involving in general meeting are used as indicators to measure the internal challenges of the cooperatives.

Limitation on the Capacity of Management Committee: The organizational structure of cooperatives is made up of three tiers: General Assembly, management committee and employees. Each structure has explicitly specific duties and responsibilities stated in the by-law of the cooperatives. The management committee is delegated by the general assembly which is responsible for managing operating polices and supervising of cooperative business performances. To identify the extent of capacity of management 
committee a question was raised. Accordingly, 38.1\% of the respondents responded that their cooperatives were highly suffered because of limited capacity of management, $22.7 \%$ of the respondents responded that their cooperatives were importantly suffered because of limited capacity of management, 19.6\% less suffered and $16.5 \%$ and $3.1 \%$ responded as not suffered and not sure respectively.

1. Inadequate internal capital: Adequate capital is one of the fundamental requisites for the sound cooperatives business operation. From the stand point of ownership, there are two kinds of capital equity and debt capital. Equity capital is provided by the members'; owners of the business. In the balance sheet it is referred to as the net worth. It is the equity that the owners have in the business which left when the total liabilities are subtracted from the total assets. Ideally the members of cooperatives should provide the capital to finances its operations. Since the cooperative exists to deliver benefits to its members, each member should contribute to capital in direct proportion to usage of services the cooperative provides. To identify the adequacy of internal capital the researchers asked respondents and the response given as a result $89.69 \%$ were responding as challenging, $17.5 \%$ as challenging, $15.5 \%$ as less challenging and $8.2 \%$ and $3.1 \%$ as not challenging and not sure respectively.

2. Embezzlement /Misappropriation: As it is known, embezzlement is taking money or property for personal use that has been given on trust by others without their knowledge or permission. Contrary to this value of cooperatives, agricultural cooperatives in the study area remain a victim of this type of malpractices. The researchers asked respondents and the response given as a result $86.69 \%$ were responding as challenging, $20.5 \%$ as challenging, $15.5 \%$ as less challenging and $8.2 \%$ and $3.1 \%$ as not challenging and not sure respectively.

3. Lack of Sense of ownership: unlike other business organizations, cooperatives are controlled, managed and owned by the users. To solve the commonly felt problems, members should first feel sense of ownership and develop economic interest on their organizations. If a member having a sense of ownership, she/he will be participated in any business activities of the cooperatives through effective management, participating in meetings and related activities. Accordingly, $38.1 \%$ of the respondents responded that their cooperatives were highly suffered because of limited capacity of management, $22.7 \%$ of the respondents responded that their cooperatives were importantly suffered because of limited capacity of management, $19.6 \%$ less suffered and $16.5 \%$ and $3.1 \%$ responded as not suffered and not sure respectively. But the focus group discussion result shows that most of the members are lacking sense of ownership.

4. Lack of Equal Opportunities in Passing Decisions: According to ICA (1996), cooperatives are democratic organizations controlled by their members who actively participate in setting their policies and making decisions. Men and women serving as elected representatives are accountable to the membership. In primary cooperatives, members have equal voting rights (one member, one vote) and cooperatives at other levels are organized in a democratic manner. To assess whether members have equal opportunities of passing decisions, the researchers evoked a question to respondents, hence, they forward $66 \%$ as most challenging, $10 \%$ challenging , $7.7 \%$ less challenging and $15.5 \%$ and $1 \%$ not challenging and not sure respectively.

\section{Weak Culture of Working Together Through Mobilizing their Resources}

There is a saying which confirms the above: "Ethiopians have the culture of eating together". However, this culture is not observed at commitment to work. In these days, government is encouraging rural people to organize themselves under agricultural cooperatives in order to achieve a better result through collective effort. But for people who have no habit of working together by mobilizing their resources collectively to achieve a better result, it is difficult to exert their maximum effort for the success of their cooperatives. Most of the time people wish to enjoy benefits at the expense of few hard worker individuals. Most of the agricultural cooperative members do not participate in the day to day affairs of cooperatives regularly and also they do not avail themselves on meetings. This is confirmed by the Personnel of marketing and Cooperative Promotion Office who consults agricultural cooperatives. He said that, usually only few individuals are convinced on the idea of working together and exert their maximum effort for the success of their cooperatives.

The researchers visited the working place of a cooperative engaged in multipurpose activities to assess whether members avail themselves in the day to day affairs of their cooperative or not .Unfortunately most of the members were not in the place because they gave priority for their private tasks.

6. Lack of Commitment of Members in their Cooperatives

The basic tool for the success of any kind of business is strong commitment of its members to serve their business honestly. Like other business institutions agricultural cooperatives success is determined by its members' loyalty in their organizations. But when we observe the history of cooperative movement in Ethiopia there is a big shadow which was observed during the military regime regarding to loyalty. At that time most of the members joined cooperatives without their interest through government enforcement. Due to that most of the members were not benefited from their cooperatives. As a result of this bad history, currently members also feel that the assets of their cooperatives are corrupted by few members. Respondents during the focus group discussion said that they became simply members of cooperatives to get fertilizer and they did not expect other benefits from their 
cooperatives, because at the end of the financial period there was no surplus which is distributed to members.

7. Little awareness about cooperatives

In cooperatives, it is expected that all members, management committee and paid managements must be aware about concept of cooperatives, benefits of cooperatives, cooperative proclamation No. 147/98, cooperative management, membership rights and duties, and by-laws of the cooperatives. When the awareness level of members is high, it is believed that there will be good management and cooperative growth. Respondents during the focus group discussion said that members have little awareness on concept of cooperatives, benefits of cooperatives, cooperative proclamation No. 147/98, cooperative management, membership rights and duties, and by-laws of the cooperatives, knowledge about cooperatives concepts, values and principles is little.

\section{Low participation of members in their cooperatives' business transactions}

According to Federal cooperative Agency (2008), the democratic control will be effective only when there is active participation of members. The active participation of member - patrons in the control and management is very essential for efficient functioning of cooperatives. Members actual participation in the control of cooperatives include attending and participating in membership meetings, taking part in voting, contesting in election, serving in one or more committees, careful study of the reports presented, extending continuous support and showing genuine interest in the affairs of cooperatives. The Focus group discussion and key informants interview result contradict with the survey result; as they responded members' participation in business was very low.

\section{Members are not actively participating in the general assembly meetings}

Through legitimate representatives, involvement of member cooperative societies in annual and emergency general assembly meeting of the cooperatives for performing different activities of the cooperatives. General assembly means a meeting of members of cooperatives. The supreme organ of any society shall be the general assembly (article 20 of proclamation No 147/1998)

10. Lack of trust: Trust is the member's confidence or faith towards the cooperatives, management committee, and employees. It was assumed as if members have confidence/ faith towards the above; they will participate in business practices of the cooperatives. The survey result indicates that the majority of the respondents have no trust towards the board of directors and the employees. There were members who have no trust towards the management body, and employees. They expect the exaggerated benefit from their products. Members see their cooperatives as profit making organizations. There were also management bodies that have no trust towards the members in terms of product provision and loan repayment.

11. Inaccessibility to credit and slow response to the credit request: Adequate capital is one of the fundamental requisites for the sound business operation of cooperatives business. From the stand point of ownership, there are two kinds of capital: equity and debt capital. Equity capital is provided by the members' owners of the business. In the balance sheet it is referred to as the net worth. It is the equity that the owners have in the business the Birr left when the total liabilities are subtracted from the total assets. Ideally the members of cooperatives should provide the capital to finances its operations. Since the cooperatives exist to deliver benefits to its members, each member should contribute to capital in direct proportion to usage of services the cooperative provides.

12. Fail to serve the members' interest: In its very principle, any cooperative society is formed to serve the common interest of the members forming it. The society which is not serving the interest of its members cannot continue functional because the members' participation is mandatory for its survival. But if the interest of the members is not served, members will not actively participate in the activities of that society. Of course their failure to serve the members' interest is linked with the following reasons:

A. Little knowledge about cooperative proclamations, rules and bylaws: some committee members said that they have little knowledge about cooperative proclamations, rules and by laws. Hence, they fail to discharge the responsibilities entrusted to them in the by-laws.

B. Limited training opportunities: even if it is the duty of the cooperative promotion office, being with other concerned bodies, to capacitate the management bodies of the cooperatives, majority of the participants in this focus group discussion reported that they get capacity building training rarely. Hence, the management committee members have weak management capacity. As a result they fail to evaluate the performance of their society and take corrective actions.

14. Lack of professional skilled manpower: In the study area, the societies are managed by committees having no cooperative background. Whereas, in principle, cooperatives have unique features for which professionals having cooperative background are needed to handle technical aspects of the society. Failure to report timely and reluctant to conduct general body meeting is another worst scenario emanated from lack of qualified leader.

15. Lack of Leadership skills: Cooperatives need leadership skills to conduct their day to day tasks in an effective manner. Leadership includes the competence to influence, inspire, unite, direct, encourage, motivate, induce, move, mobilize, and activate others to pursue a common goal or purpose while maintaining commitment, momentum, confidence and courage. Most of the cooperatives were in great problem because of lack of skilled manpower to lead their day to day activities. From the interview with one of the key informants, the marketing and cooperative 
promotion office personnel, it was understood that most of the agricultural cooperatives in the study area were led by individuals who had no leadership skills. The committee members who participate in the day to day affairs of cooperatives were elected without taking into consideration their ability to organize the staff, coordinate and lead members towards their common goals. They were simply elected by the members through their position in the village. According to the cooperative bureau personnel, members try to abstain themselves from being leaders because the position requires devotion and demands the leader to spend a lot of time at risk.

\section{Lack of Transparency}

It is the existence of the free flow of information. All process, decisions and relevant information should be conducted in a transparent manner and should be accessible to all those concerned. Enough information is providing to understand and monitor them, consensus on the best interest of the group, on policies and procedures. Most of the respondents responded that there was no the existence of the free flow of information and all process, decisions and relevant information were conducted in a transparent manner and accessible to all concerned bodies. As the result of the survey conducted indicates, the majority of the respondents responded there was no transparency in the cooperatives.

\section{External Challenges}

Cooperatives work in an environment where most profit oriented private enterprises compete for each other. The situation of members and the place where they are located have vital role in either impairing their movement or enhancing their performances. The stiff competition in the external environment is beyond the control of cooperative members as well as management and seems unhealthy competition.

\section{Conclusion and Recommendations:}

The study was conducted with the objective of assessing the challenges and prospects of agricultural cooperatives in South Gondar Zone, North West Ethiopia. The major findings of the study are summarized and the researchers have forwarded the recommendation as follows.

Findings of the study revealed that the most visible prospects for agricultural cooperatives in South Gondar Zone were existence of legal framework, Cooperative Unions Support to agricultural cooperatives by providing training to members, women involvement in leadership, awareness creation, and trained members' Positive attitude towards cooperatives.

Also findings of the study revealed that agricultural cooperatives in the study area faced many challenges that are internal and external in nature. The internal challenges were seen from the perspective of members and management committee.

Challenges from the perspective of members: the major challenges for cooperative growth from the perspective of members were lack of sense of ownership and their failure to follow up and control their cooperative societies' activities, weak culture of working together through mobilizing their resources, lack of commitment of members in their cooperatives, members little awareness about cooperatives, low participation of members in their cooperatives' business transactions, members are not actively participating in the general assembly meetings, members suspect the management body and the management body also suspects members and some members' intention to sell their products to private merchants.

Challenges of agricultural cooperatives from the perspective of management committee were failure of management committee to serve the members' interest; management committees' little knowledge about cooperative proclamations, rules and by laws, limited training opportunities, long distance to be travelled, lack of leadership skills and embezzlement.

From the perspective of appropriate authority at zonal and woreda levels ; limited professional support and follow up to cooperatives; they fail to adapt the experience of other model cooperatives; there is lack of commitment to build better image of cooperatives at different levels, there is little effort to promote cooperative policies, strategies, proclamations, rules and regulations, lack of commitment to find out the problems of cooperatives and fill the gap; fail to organize and provide adequate, quality and timely information on cooperatives and high employee turnover at zone and woreda levels.

\section{Recommendations:}

\section{Activities to be undertaken to transform agricultural cooperatives in the study area}

The Advanced cooperative certification system classifies and certifies cooperatives based on a comprehensive set of criteria. Public certification allows third parties to identify and work with capable cooperatives by providing a clear indication of their performance in several areas. Simultaneously, it provides the opportunity to flag underperforming cooperatives for capacity building and training initiatives. The Federal Cooperatives Agency (FCA) has developed a framework of certification directives and criteria, as well as designing and setting up a structure for certifying bodies at federal and regional levels. 


\section{As much as possible, inviting cooperative professionals to lead the sector}

Cooperative management, though applies all modern management techniques, has its own special features. Cooperatives have to first follow the principles of cooperation laid down by International Cooperative Alliance, and then they have to go for applying the management process. It has to keep a balance between these two. The proper application of cooperative principle is necessary for the success of the movement, for cooperative principles is those which are essential that is absolutely indispensable to the achievement of cooperatives movements' role. In this regard, professionals working must be those who know the special features of cooperative business.

\section{Training to office bearers and education to the members pertaining to their specific needs}

The fifth Principle of cooperatives state that cooperatives must provide education and training for their members, elected representatives, managers and employees so they can contribute effectively to the development of their cooperatives. But in most of the agricultural cooperatives in the study area, members and elected representatives are getting training and education seldom. This situation has significant impact on the growth of their cooperatives. Therefore, the concerned bodies have to provide the training to office bearers and education to the members. Educating cooperative members can help encourage them to become more involved and committed to the cooperatives.

In addition in order to overcome non member farmers' awareness problem, cooperatives should facilitate training programs to potential members. The training strategy of the cooperatives should focus on experience sharing in the area of cooperative and importance of the cooperatives. Hence more training should be given to stimulate interests and commitment of members and management committee and potential members. In order to increase farmer participation, there is a need to create more campaigns about the benefits of being in the cooperatives. The management of the cooperative and local government officials needs to work together and refocus their efforts towards mobilizing more farmers into the members of the cooperatives thereby to bring cooperative growth.

Most of the members of agricultural cooperatives are above the age of 30 in which youth are not more engaged. Therefore, great attention should be given to active age group to motivate them to contribute in every aspect of the cooperatives as a member.

Some degree of members' turnover is inevitable, but successful cooperatives will retain their members. The cooperatives should assure the continuity of existing members through good cooperative management practices and provision of good service for their members.

Members are the lifeblood of any cooperative societies. Agricultural cooperative membership growth brings new equity, financial strength, increases business volume, helps developing economies of scale and improves the performance of the cooperatives. But membership growth trend of sampled agricultural cooperatives was below the established standard. Therefore, propagating the philosophy and benefits of agricultural cooperatives to the general public mainly to the youth helps to bring new heads to the cooperatives and it is very important for the sustainable development of cooperatives.

Prospects for the agricultural cooperatives in the study area: The existence of clear governmental policy and supportive legal framework are essential pre requites in creating conducive environment for cooperatives growth and to facilitate the development of sustainable, efficient and effective rural organizations. A true policy environment that is supportive and responsive to the interest of rural constituencies, including the poor, is paramount importance. It is, therefore, possible to state conducive policies and appropriate legal framework as one of the opportunities for the proliferation of agricultural cooperatives. In this regard, long after the 1991 political reorientation in Ethiopia, cooperative society's proclamation No.147/ 1998 has been formulated. The proclamation includes, among other, the basic International Cooperative Alliance principles of cooperatives. It is believed that the proclamation is a comprehensive and relatively democratic to potentially address the needs and aspirations of members of the cooperative society in Ethiopia. Aware of the above justification and the underlying rationales of the legal framework for cooperative growth the researchers found the following opportunities provided to cooperatives as responded by the respondents.

Cooperative experts and the NGO representatives working on cooperatives indicated that the legal framework is workable and somehow conducive. The respondents further revealed that the disparity lies between the defective legal framework of the Derg with aggressive government authorities to channel the socialist ideology provisions versus the relatively conducive legal provisions with inefficient government officials and cooperative leaders at different level of the cooperative bureaucracy. Therefore, it should be taken into consideration that appropriate legal provisions such as the proclamation and by-laws are necessary but not sufficient conditions for the growth of efficient cooperative; inappropriate legal framework is not solely responsible for unsatisfactory cooperative growth.

However, some respondents believed that there are still gaps in fulfilling all the privileges given in the proclamation No.147/98, which state that the government providing enough support to cooperative form of business like acquiring land, getting credit through the collateral of the government and getting audit services free 
of charge once in a year are not in a way that can fulfill the demand of their cooperatives. Further, according to woreda level cooperative promoters' opinion, cooperatives began to receive consistent and effective technical and administrative support after the establishment of independent cooperatives promotion office; however their support could not go longer in a sustainable way to these cooperative societies.

To conclude, the legal framework creates opportunities for the cooperatives in the study area in a better manner than the previous governments. However, still there are gaps in realizing the legal frame work taking the unique nature of these societies. The gap emanates both from inefficient government officials and cooperative leaders at different level of the cooperative bureaucracy and the impractical of the government promise that expected to provide a special privilege to these cooperatives. Therefore, the researchers concluded that in order to establish a cooperatives society in a sustainable manner, these gabs that bottlenecked the legislation of the government should be averted.

Due to support of the unions in terms of marketing, training and education, collecting the input demand of each farmer member through one to ten groups of the members' net working, members become aware about the benefits of saving, how to use inputs and planning.

Almost all member farmer respondents' agricultural cooperatives are selling their coffee through the cooperatives. The other opportunity is that most of the farmers sell products to cooperatives. If this is the case, business transaction of the cooperatives increases and growth of the cooperatives is ensured.

The member farmer in agricultural cooperatives attitude towards their cooperatives is positive: most of the members have positive attitude towards their cooperative because their living standard is improved after becoming members in the cooperatives.

Women involvement in leadership: in some cooperatives women are engaged in leadership position. This empowers women both economically and socially. This in turn attracts other women to the cooperatives. This is particularly true in multipurpose agricultural cooperative.

Among the total population of the zone almost less than $45 \%$ are member of cooperatives. Education and Training program as a strategy should be designed. To be successful, cooperatives must conduct education and training programs as per the needs of their members, board members and employees.

Most of agricultural cooperatives have large area which helps to collect large product to be marketed internationally. Although such signs of success are there, greater efforts should still be made to organize, promote and develop cooperatives in the country through increasing members' commitments. Based on the principles of cooperatives, agricultural cooperatives are expected to genuinely perform their marketing activities and provide adequate services to their members.

\section{Reference}

- Agricultural cooperative sector development strategy 2012-2016.

- Federal cooperative agency .(2014). Annual Publication, Vol1,No11

- BEST, J. R. (2005). Market-Based Management: Strategies for Growing Customer Value, 4th Edition, Prentice Hall of India. journal of marketing.

- ETHIOPIA, I. G. O. (1960). Commercial Code of the Empire of Ethiopia of 1960, NegaritGazeta Extraordinary Issue No. 3 of 1960, Addis Ababa.

- NEGARITGAZETA, F. (1998a). Cooperative Societies (Amendment) Proclamation No. 402/2004, Addis Ababa, Ethiopia.

- NegAritgazETA, F. (1998b). Cooperative Societies Proclamation No. 147/1998, Addis Ababa, Ethiopia.

- SERVICES, P. C. A. I. (2006). Developments in Saving and Credit Cooperatives in Ethiopia: Evolution, Performances, Challenges and Interventions with Particular Emphasis on RUSACCOs (September): Addis Ababa, Ethiopia.

- Alemayehu. (1984). State commerce and service cooperative in Kembata and Hadiya Zones: an economic geography analysis. Unpublished master's thesis, School of Graduate Studies, Addis Ababa University, Addis Ababa.

- Azmah Othman (2012).Factors Influencing Cooperative Membership and Share Increment: An Application of the Logistic Regression Analysis in the Malaysian Cooperatives.

- Bijman, J. (2002), Essays on Agricultural Co-operatives; Governance Structure in Fruit and Vegetable Chains, Rotterdam: ERIM (PhD Thesis).

- Chambo et al. (2007). An Analysis of the Socio-economic Impact of Cooperatives in Africa and their Institutional Context, ICA Regional Officer for Africa, Nairobi,

- Daniel Belay, 2006. Performance of Primary Agricultural Cooperatives and Determinantsof Members' Decision to use as Marketing Agent in Adaa Liben and Lume Districts, Ethiopia.

- Dessalegn Rahmato (1992). Rural Organization in Ethiopia: A Report Prepared for FAO, Institute of 
Development Research, Addis Ababa University, Addis Ababa.

- Dorsey.J, Tesfaye Assefa (2005). Find Evaluation Report of Agricultural Cooperatives in Ethiopia (ACE) Program Activities. USAID, Washington, D.C.

- $\quad$ FCA (2010). Annual Publication of the Federal Comparative Agency Public Relation Department; Volume 7, No 4, Addis Ababa, Ethiopia.

- FCA (2007). Annual Report for the Year 2004/2005. Unpublished Document, Addis Ababa, Ethiopia.

- Federal Cooperative Agency (2006). Annual Magazine Published by Public Relations Section of the Cooperative Agency. Vol.3 No.1, Addis Ababa, Ethiopia.

- Federal Negarit Gazta of the EPRDF (1998) cooperative society's proclamation No.147/1998, Addis Ababa

- Folsom, J., 2002. Measuring impact of cooperatives in Minnesota. Minnesota: USDA/ Rural Development.

- Getenesh S. (1988). Result analysis and result comparison of farmers' producers' cooperatives in the highlands of Hararghe. Unpublished master's thesis, School of Graduate Studies, Alemaya University of Agriculture, Alemaya. Presented at the Fourth Conference of the Agricultural Economics Society of Ethiopia, Addis Ababa

- Haile selassie G, (2003). The Benefits of Cooperative Membership: A Cooperative Study in Saesie Tsaeda Emba District, Tigray Region, Ethiopia. MSc. Thesis, Submitted to Department of Food Business and Development, National University of Ireland, Cork.

- Hajela, T.N. (1990). Principles, Problems, and Practices of Cooperation. Shivalal Agrawala \& Co Agra. New Delhi.

- Holloway, et al. (1999) “Agro Industrialization through Institutional Innovation: Transaction Costs, Cooperatives and Milk-Market Development in the Ethiopian Highlands. International Food Policy Research, Washington DC.

- Hussi et al., (1993): The Development of Cooperatives and Other Rural Organization: The Role of World Bank, World Bank Technical Paper No.199, Africa Technical Department Series, The World Bank Washington, D.C.

- ICA. (1995). Statement on the Cooperative Identity. Geneva, Switzerland.

- ICA. (1996). Statement on the Cooperative Identity. Geneva, Switzerland

- ILO (2000).Cooperatives and the MDGs, Cooperative Branch and Policy Integration. Geneva, Switzerland Journal of African Economies, (2011). Ethiopian Agricultural Cooperatives in an Era of Global Commodity Exchange, Addis Ababa. 